\title{
A case of aberrant lacrimal gland and fistula
}

\author{
GÜLCAN KURAL, ARIF SERIFOĞLU, AND SAADET ERTÜRE \\ From the Numune Hospital, Ankara, Turkey
}

SUMmARY A case of aberrant lacrimal gland and fistula sited extraorbitally is presented in view of its rare incidence.

An aberrant lacrimal gland is a rare abnormality. We report here a case observed in the Clinic of Ophthalmology, Numune Hospital, Ankara.

\section{Case report}

A 9-year-old boy was seen in September 1987 with the complaint of constant watering since birth from the middle of the right temporal region, where the skin was never free of tears. The watering increased on weeping.

On examination, a small orifice could be seen in the skin in the middle of the right temporal region. The opening was round and $1 \mathrm{~mm}$ in diameter. Clear transparent fluid could be seen continually flowing from the orifice (Fig. 1). There was no evidence of excoriation, inflammation, or swelling round the opening. Apart from this condition both eyes, including the lacrimal apparatus, were normal in all respects. There was no other congenital abnormality in the eyes or elsewhere.

Correspondence to Dr Gülcan Kural, Clinic of Ophthalmology, Numune Hospital, Ankara, Turkey.

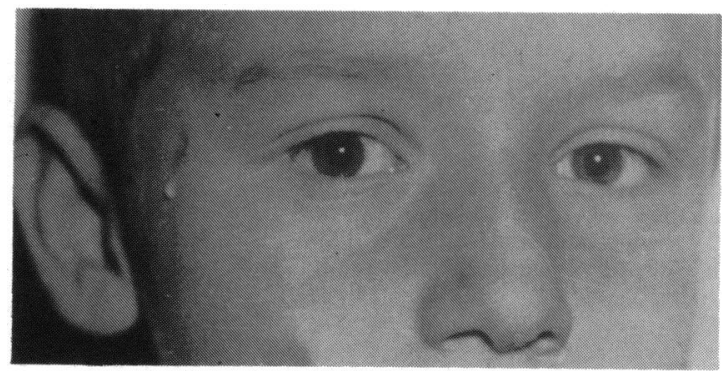

Fig. 1 Clear transparent fluid continually discharged from the orifice.
A quantitative biochemical assay of the transparent fluid coming from the orifice, which was consistent with that of tears, was done. A fine catheter could be passed into the fistula for about $0.5 \mathrm{~cm}$ in the direction of the external canthus. Radiological examination after injection of radioopaque dye showed the dye in the fistula. The investigations confirmed that the fluid coming from fistula was tear secreted by an aberrant lacrimal gland.

The patient was operated upon. After skin incision had been made and a probe passed, the fistula and the gland, which was $0.5 \times 0.8 \times 1.6 \mathrm{~cm}$ in size, were dissected out from the surrounding tissues. The gland with the fistula was completely removed. The postoperative course was normal.

Microscopic examination of the specimen showed a glandular tissue similar to that of lacrimal gland (Fig. 2).

\section{Discussion}

An aberrant lacrimal gland is an unusual congenital and developmental abnormality and differs from an ectopic gland. ${ }^{1}$ The first case of aberrant lacrimal gland associated with other congenital abnormalities was reported by Gördüren in 1962 in Turkey, ${ }^{2}$ and in 1963 a second case was also reported by the same author. ${ }^{3}$ Firat and Emüler ${ }^{4}$ described two cases of aberrant lacrimal gland in the bulbar conjunctiva. Slem $e t$ al. reported a case of aberrant lacrimal gland in the orbit. ${ }^{5}$ Our case is a typical example of an aberrant lacrimal gland, and we believe it to be the sixth case from this country to be published.

Dr Ayşe Ayhan examined the sections of the specimen and we are indebted to her for the histopathological diagnosis. 


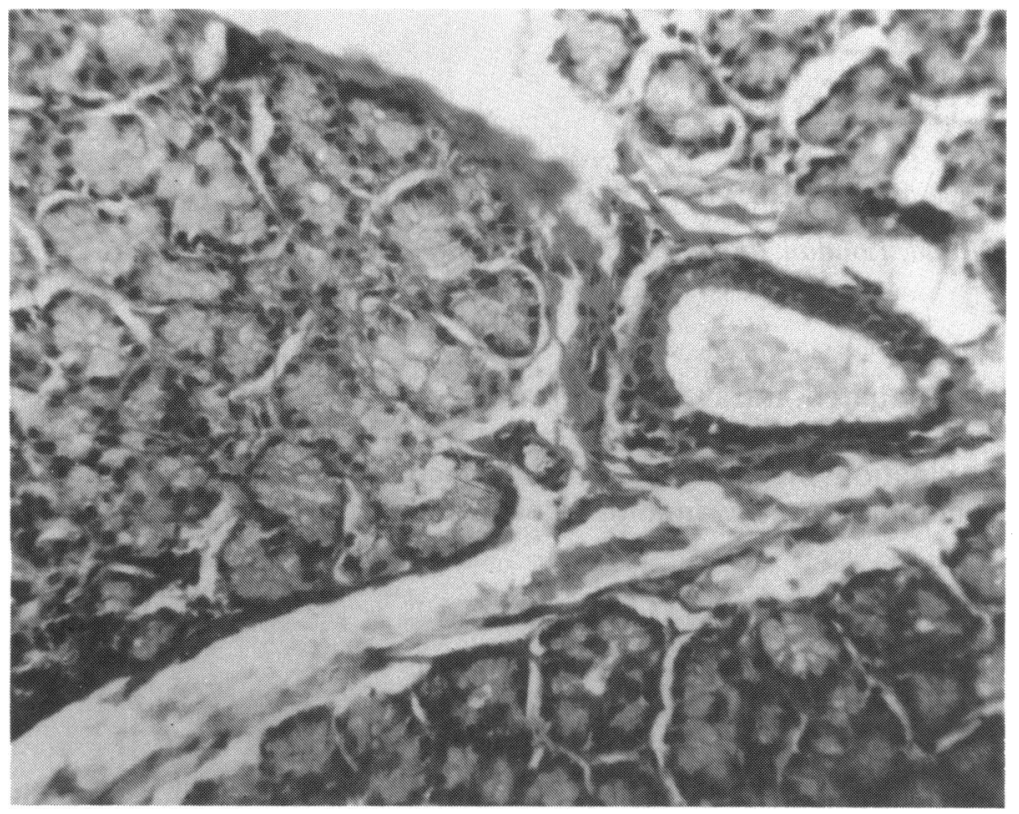

Fig. 2 Glandular acini observed in the microscopic sections.

(Haematoxylin and eosin, $\times 240$.)

\section{References}

1 Duke-Elder S. Normal and abnormal development. In: DukeElder S, ed. System of ophthalmology. London: Kimpton, 1964; 3: 917-23.

2 Gördüren S. Aberrant lacrimal gland associated with other congenital abnormalities. Br J Ophthalmol 1962; 46: 277-80.

3 Gördüren S. Iki vaka münasebetiyle aberan gözyaşı bezi. Istanbul Göz Klin Bült 1963; 21: 59-63.
4 Firat T, Emüler Ü. Two cases of aberrant lacrimal gland. Ann Ophthalmol 1970; 2: 50-1.

5 Slem G, Ilçayto R, Baykal E, Turan S. Orbitaya yerleşmiş ve dakrioadenit yaparak ekzoftalmus yaratan bir aberrant lakrimal gland vakası. VIII Ulusal Türk Oftalmoloji Kongresi Bülteni (28 Eylül-2 Ekim 1970, Izmir). Izmir: Karınca Matbaacılık, 1971: 264-8.

Accepted for publication 4 August 1988. 